\title{
Strategi Pengembangan Industri Kain Tenun Endek Di Kota Denpasar Era Revolusi 4.0
}

\author{
Ni Putu Nina Wartika Dewi, Ni Putu Nina Eka Lestari \\ Universitas Pendidikan Nasional \\ Postgraduate Management, Undiknas Graduate School, Bali, Indonesia \\ Email: ninawartika@yahoo.co.id
}

\begin{abstract}
Abstrak: Studi ini bertujuan untuk mengetahui faktor- faktor apa saja yang menjadi kekuatan dan kelemahan dalam pengembangan industri kerajinan kain tenun di kota Denpasar pada era revolusi 4.0. Selain itu, studi ini juga mempunyai tujuan untuk mengetahui startegi pengembangan industri kerajinan kain tenun, sebagai bagian dari sektor UMKM pada era revolusi 4.0. Penelitian ini menggunakan pendekatan kuantitatif, dengan analisis deskriptif, melalui proses analisis faktor-faktor ekternal dan internal yang memperngaruhi perkembangan kain tenun endek di kota Denpasar. Penelitian ini melakukan pengumpulan data menggunakan kuesioner, observasi dan dokumentasi yang selanjutnya di analisis dengan teknik analisis SWOT membandingkan faktor internal dan eksternal hingga dapat menentukan Matriks SWOT dan Matriks IE untuk penentuan strategi. Hasil dari penelitian ini menunjukan bahwa strategi yang sesuai dengan kondisi industri kain tenun endek berada pada kuadran satu adalah grown strategy pada matriks SWOT, sehingga mampu memaksimalkan kekuatan internal untuk mengembangkan peluang yang ada. Posisi bisnis industry kain tenun endek pada kuadran ke $\mathrm{V}$ dan strategi yang sesuai adalah strategi pertumbuhan dengan konsentrasi melalui integrasi horizontal.
\end{abstract}

Kata kunci: UMKM, industri kain tenun endek, Analisis SWOT

\begin{abstract}
This study aims to determine strengths and weaknesses factors in development of the woven fabric industry in Denpasar during revolutionary of 4.0 era. In addition, this study sets the objective to determine strategy for development of the woven fabric industry, as part of MSME's sector during revolutionary of 4.0 era. This research uses a quantitative approach, with descriptive analysis, through a process of external and internal factors analysis, which could influence the development of endek woven fabrics in Denpasar. This study collects data using a questionnaire, observation and documentation which is then analyzed using the SWOT analysis technique, comparing internal and external factors, so it can determine the SWOT Matrix and IE Matrix for strategy determination. The results of this study indicate that strategy which suits conditions of the endek woven fabric industry in quadrant one is a grown strategy in the SWOT matrix, so as to maximize internal strength to develop existing opportunities. The business position of the endek woven fabric industry is in the V quadrant and an appropriate strategy is a growth strategy with concentration through horizontal integration.
\end{abstract}

Keywords: UMKM, Endek woven fabric industry, SWOT analysis

\section{PENDAHULUAN}

Kebijakan yang dikeluarkan Gubernur Bali tentang Peraturan Gubernur (Pergub) no 79 Tahun 2018 yang mengatur hari pengunaan busana adat Bali, mulai menunjukkan dampak positif. Pengaturan pengunaan busana adat bali itu diluncurkan untuk memperkuat adat dan budaya Bali. Pemerintah awalnya berharap, melalui Pergub ini, para pelaku usaha mikro, kecil, dan menengah (UMKM), pedagang, pengusaha, di bidang pakaian adat Bali merespons dan memanfaatkan peluang ini. Dengan adanya peraturan mengenai berbusana adat Bali ini, kini para pengusaha dan produsen pakaian adat Bali menerima kenaikan jumlah pesanan. Salah satu poin penting dari Pergub ini adalah mewajibkan minimal 


\section{Forum Bisnis Dan Kewirausahaan Jurnal Ilmiah STIE MDP}

enam kali dalam sebulan, bagi karyawan untuk berpakaian adat Bali.

Usaha Kecil Mikro dan Menengah (UMKM) mempunyai peran yang strategis dalam pembangunan ekonomi nasional. Peran tersebut yaitu berperan dalam pertumbuhan ekonomi dan juga berperan dalam pendistribusian hasil-hasil pembangunan (Singgih, 2006).

UMKM di Indonesia mencapai lebih dari 90\% dari semua perusahaan di luar sektor pertanian. Oleh karena itu, UMKM dipandang sebagai sumber terbesar dari lapangan pekerjaan dan menyediakan pendapatan utama bagi lebih dari $90 \%$ dari negara tenaga kerja (Bhasin, 2010:02).

Berdasar data yang diperoleh, pada tahun 2019, terdapat 265.558 UMKM di seluruh Bali. UMKM terbanyak terdapat di Kabupaten Gianyar (91.511), Karangasem (38.954), Bangli (35.263), Badung (26.863), Jembrana (20.512), Tabanan (20.032), Denpasar (11.515) Buleleng (11.196), Klungkung (9.712). Dari segi besarnya usaha, yang menonjol di Denpasar (Dinas Koperasi Kota Denpasar, 2019).

Meningkatnya perkembangan UMKM di Kota Denpasar selama lima tahun belakangan ini, tidak lepas dari perhatian serius serta dukungan Pemeritah kota Denpasar. Perkembangan UMKM selama ini didukung oleh pemberian kemudahan terhadap perizinan, membantu permodalan UMKM melalui Kredit Usaha Rakyat (KUR), melaksanakan monitoring dan evaluasi yang dilaksanakan oleh Dinas Koperasi dan UMKM Kota Denpasar, Dinas Perindustrian dan Perdagangan Kota Denpasar (Sukaatmadja, 2014).

UMKM pun tumbuh dan terus berkembang sehingga mampu mendukung pergerakan roda perekonomian di Kota Denpasar. Perkembangan UMKM dari tahun 2013 jumlah UMKM di Kota Denpasar sebanyak 11.575 UMKM, tahun 2014 meningkat menjadi 11.877 UMKM, tahun 2015 meningkat menjadi 11.905 UMKM, dan tahun 2016 meningkat drastis menjadi 30.761 UMKM, sedangkan pada tahun 2017 lalu jumlah tersebut meningkat menjadi 30.840 UMKM dan 2018 menjadi 31.826 UMKM (Dinas Koperasi Kota Denpasar, 2019).

Terdapat 3 UMKM yang mendominasi diantara nya UMKM bidang Kuliner yang tersebar di kota Denpasar Mikro 2.7929 UMKM, Kecil 479 UMKM, Menengah 445 UMKM. UMKM Bidang Fashion Mikro 34.114, Kecil 455 UMKM, Menengah 325 UMKM, dan UMKM bidang Kerajinan Mikro 9.915 UMKM, Kecil 324 UMKM, dan Menengah 103 UMKM. UMKM bidang fashion adalah yang paling besar yang ada di Kota Denpasar.

Namun, UMKM produk kain tenun endek, sebagai kain khas pakaian adat Bali di Denpasar, masih terbilang cukup sedikit. Hal ini disebabkan oleh beberapa faktor, salah satunya para pengrajin kurang mampu berinovasi pada produk yang dihasilkan, sehingga UMKM produk kain tenun endek kurang mampu dalam bersaing guna meningkatkan kinerja pemasaran (Dinas Koperasi Kota Denpasar, 2019).

Kebutuhan kain tenun endek meningkat, mulai meningkat dengan dikeluarkannya Pergub No 79 Tahun 2018 Hari Penggunaan Busana adat Bali, yang mewajibkan menggunakan pakaian adat 5 kali dalam sebulan. Hal ini menjadi peluang produksi kain tenun endek dari daerah lain, yang memiliki kualifikasi sama dengan kain tenun endek peoduk lokal memenuhi pasar lokal. Hal ini sangat disayangkan oleh para pengrajin, dimana produk lokal tidak mampu bersaing di pasar lokal.

Banyak hal yang menyebabkan permasalahan tersebut. Hasil pra observasi menyebutkan, alasan pertama disebabkan oleh proses yang panjang, kurangnya pemberdayaan sumber daya manusia khususnya generasi muda, dan lamanya proses pembuatan. Hal ini berdampak pada meningkatnya harga kain produksi lokal, selain itu variasi motif yang dihasilkan oleh pengrajin cenderung monoton, sehingga saat masuknya kain tenun dari daerah lain yang memiliki motif baru akan menarik daya pikat konsumen. 


\section{Forum Bisnis Dan Kewirausahaan Jurnal Ilmiah STIE MDP}

Kemunculan teknologi di tengah era revolusi industri 4.0, memberikan tantangan baru bagi pelaku UMKM untuk berinovasi dan beradaptasi dengan teknologi yang ada (Fitriasari, 2017). Dengan adanya digitalisasi yang terkoneksi luas maka pelaku usaha UMKM dapat menyebar luaskan barang atau jasa yang mereka perjual belikan (Ardiansyah, 2016).

Dengan kata lain, kemajuan industri menciptakan pasar yang luas sehingga dapat menambah keuntungan bagi UMKM itu sendiri. Apabila revolusi industri 4.0 ini mampu direspons dengan baik oleh pelaku industri kain endek di Kota Denpasar, maka mereka dapat meningkatkan kinerja usahanya untuk lebih efektif dan sukses ke depannya. Di sisi lain, revolusi industri 4.0 juga membawa angin segar bagi pengusaha UMKM kain tenun endek di Kota Denpasar, dalam memacu produktivitas mendorong inovasi teknologi, dan memfasilitasi inkubasi bisnis.

Studi ini bertujuan untuk mengetahui faktorfaktor apa saja yang menjadi kekuatan dan kelemahan dalam pengembangan industri kerajinan kain tenun di kota Denpasar era revolusi 4.0. Selain itu, studi ini juga mempunyai tujuan untuk mengetahui startegi pengembangan industri kerajinan kain tenun di kota Denpasar era revolusi 4.0.

\section{KAJIAN LITERATUR}

Strategi merupakan suatu proses penentuan rencana para pemimpin puncak yang berfokus pada tujuan jangka panjang organisasi, disertai penyusunan suatu cara atau upaya bagaimana agar tujuan tersebut dapat dicapai (Stephanie, 2018).

Menurut Umar, (2005) strategi merupakan tindakan yang bersifat incremental (senantiasa meningkat) dan terus-menerus, serta dilakukan berdasarkan sudut pandang tentang apa yang diharapkan oleh para pelanggan di masa depan. Adapun Rangkuti (2008), berpendapat bahwa pada prinsipnya strategi dapat dikelompokkan berdasarkan tiga tipe strategi, yaitu strategi manajemen, strategi investasi, dan strategi bisnis.
Strategi juga berkaitan erat dengan pengembangan suatu organisasi. Iban (2015:23-30) merumuskan definisi mengenai pengembangan dalam konteks strategi yaitu memajukan dan memperbaiki atau meningkatkan sesuatu yang telah ada. Wilantara (2016:34-42) menyatakan pengembangan bertujuan untuk mengembangkan produk yang pelayanan yang berkualitas, seimbang dan bertahan.

Strategi pengembangan dibutuhkan bagi sektor UMKM (Usaha Mikro, Kecil, dan Menengah). Pemerintah melalui Kementerian Koperasi dan UMKM mendefinisikan istilah usaha kecil dan menengah dalam Undang-Undang No 9 Tahun 1995 (Sriasih, 2016).

Usaha kecil didefinisikan sebagai kegiatan ekonomi yang dilakukan oleh perseorangan dan rumah tangga maupun suatu badan bertujuan untuk memproduksi barang atau jasa untuk diperniagakan secara komersal dan mempunyai omzet penjualan (satu) miliar rupiah atau kurang. Sementara usaha menengah didefinisikan sebagai kegiatan ekonomi yang dilakukan oleh perseorangan atau rumah tangga maupun suatu badan dengan tujuan untuk menghasilkan atau memproduksi barang atau jasa untuk diperniagakan secara komersial dan mempunyai omzet penjualan lebih dari 1(satu) miliar.

Dalam menganalisis strategi pengembangan, beberapa praktisi maupun akademisi cukup akrab dengan beberapa analisis seperti Matriks TOWS atau Matriks SWOT, Matriks BCG, Matriks Internal Eksternal, Matrik, SPACE, Matriks Grand Strategy (Rangkuti, 2014). Menurut (Chandler, 2019: 43), SWOT digunakan untuk menilai kekuatan-kekuatan dan kelemahan-kelemahan dari sumber-sumber daya yang dimiliki perusahaan dan kesempatankesempatan eksternal dan tantangan- tantangan yang dihadapi.

Strategi pengembangan UMKM semakin memperoleh tantangan di era revolusi industri 4.0. Menurut Marsudi (2019) industri 4.0 pertama kali tahun 2011 di Jerman yang ditandai dengan revolusi digital. Revolusi digital diadopsi dari perkembangan teknologi komputer yang terus berkembang dari waktu 


\section{Forum Bisnis Dan Kewirausahaan Jurnal Ilmiah STIE MDP}

ke waktu. Revolusi industri 4.0 ini dimulai dari ditandai dengan dimanfaatkannya teknologi digital dan informasi sepenuhnya (Savitri, 2019:36-44).

Model bisnis modern yang digunakan saat ini sangat dinamis, sehingga mempengaruhi industri di masa sekarang yang tidak hanya berfokus pada proses produksi, tetapi juga mempengaruhi rantai nilai perusahaan (Nurjannah, 2014).

Perkembangan yang dapat dirasakan seperti integrasi pemanfaatan jaringan dengan teknologi internet dan cybernetika (Kotler, 2017:318). Revolusi industri 4.0 juga kemudian mendorong dijalankannya strategi marketing/pemasaran 4.0 yang didefinisikan sebagai pendekatan pemasaran yang menggabungkan interaksi online dan offline antara perusahan dan pelanggan, serta memadukan gaya dan substansi (Kartajaya, 2017:143).

Tahwin (2014) menyampaikan strategi pengembangan industri UMKM batik tulis Lasem. Strategi tersebut menunjukkan agar industri batik tulis lasem menjadi kegiatan ekonomi yang memiliki nilai tambah dan berdaya saing tinggi. Endaryono (2016) menyebutkan bahwa dalam kaitannya dengan motivasi dan mitra pembangun, perlu dikembangkan jaringan pemasaran dengan memanfaatkan networking serta mengembangkan quality control.

Suryadi (2018) menyebutkan bahwa untuk menghadapi tantangan dalam menghadapi perekonomian di masa yang akan datang, dibutuhkan wirausaha-wirausaha yang tahan banting, punya daya saing global dan memegang nilai-nilai luhur dan cinta pada negerinya. Kewirausahaan ini dirasakan semakin penting peranannya dalam pengembangan perekonomian nasional, serta efektif untuk meningkatkan kesejahteraan rakyat (Wahjusaputri, 2017).

Asriati (2019) menyebutkan identifikasi potensi-potensi pengembangan entrepreneurship di Bengkayang melalui pemetaan potensi usaha berbasis analisis SWOT dan GPS. Riset tersebut mampu menggali isu-isu strategis yang berkaitan dengan pengembangan enterpreneurship di Kabupaten
Bengkayang. Endaryono (2018) menyampaikan bahwa isu-isu yang sering muncul antara lain diperlukan bantuan modal kerja dalam pengembangan usaha, pembinaan dan pendampingan pelaku UMKM oleh dinas terkait, penyediaan bahan baku, penyediaan peralatan usaha, kemudahan dalam perizinan usaha, dan pemasaran produk yang dihasilkan terkordinir dalam kawasan isndustri terpadu mandiri.

Arifianto (2018) menyebutkan kajian pada industri kerajian topeng di era revolusi 4.0, menyebutkan produk kerajinan memiliki segmentasi pasar masyarakat yang lebih luas, dengan kemudahan pemasaran di era digital. Nurcahyani (2018) dalam kajiannya tentang pengembangan produk kain tenun ikat sintang menyebutkan bahwa strategi yang dilakukan berjalan dengan baik dan diperlukan keterlibatan pihak lain seperti yayasan dan Pemerintah Daerah. Lestari (2014) melalui analisis SWOT memposisikan industri UMKM kerajinan ukiran kayu adapada kuadran II, yang menandakan industri cukup kuat namun menghadapi tantangan yang besar.

\section{METODE PENELITIAN}

Penelitian ini dilakukan di kota Denpasar karena kota Denpasar memproduksi kain tenun endek yang unik, dan telah menjadi ikon Kota Denpasar. Penelitian ini dilakukan dengan pendekatan deskriptif kuantitatif.

Variabel dalam analisis SWOT yang dilakukan dalam penelitian ini digolongkan dalam empat variabel dalam dua faktor. Dua variabel pertama adalah faktor internal. Faktor internal terdiri dari kekuatan (strengths) dan kelemahan (weakness). Strength adalah kondisi kekuatan yang ada dalam industri pengembangan kain tenun endek di Kota Denpasar. Weakness adalah kelemahan di masa yang akan datang yang terdiri dari tenaga kerja, keterampilan kerja, harga produk, bahan baku, kemitraan, jangka pasar, akses modal, mutu produk, inovasi, teknologi dan marketing (Sugiyono, 2018).

Dua variael kedua adalah faktor ekternal. Faktor ini terdiri dari peluang (opportunities) dan 
ancaman (threats) (Stephanie, 2018). Opportunity adalah kondisi peluang dan kondisi yang berkembang di masa yang akan datang. Adapun threat merupakan kondisi yang mengancam dari luar indusry yang terjadi dalam industry pengembangan kain tenun endek di Kota Denpasar yang terdiri dari: dukungan pemerintah, subsidi, pesaing, jumlah penduduk, pendapatan masyarakat, hambatan masuk pasar, lingkungan bisnis, pemasok, dan perubahan gaya hidup konsumen.

Jenis data dalam penelitian ini adalah data kuantitatif yang diperoleh seperti umur, jenis kelamin, jejang pendidikan, serta nilai dari sekor dari skala liket, kuesioner yang digunakan (Umar, 2002). Data ini diperoleh melalui sumber data primer, yaitu hasil pengamatan dengan informan yaitu pelaku UMKM industri kain tenun endek di Kota Denpasar baik itu wanita atau pria dengan menggunakan kuesioner. Selain itu, terdapat juga sumber data sekunder, yang sifatnya mendukung keperluan data primer seperti buku-buku, literatur dan bacaan yang berkaitan dengan topik penelitian.

Populasi dari penelitian ini adalah industri kain tenun endek yang tegolong dalam UMKM Kota Denpasar berdasarkan jumlah pengelola (penjual) dan pengerajin, dimana yang tersebar di Kota Denpasar sebanyak 18 industri. Terdapat tiga teknik pengumpulan data yang dilakukan di penelitian ini, yaitu observasi, kuesioner, dan dokumentasi. Instrumen penelitian yang dugunakan dalam penelitian ini menggunakan deskriptif. Instrumen disebar melalui survei kepustakaan dan survei lapangan dengan obsevasi dan dengan kuesioner. Observasi dan kuesioner dilakukan langsung kepada pengelola (pedagang) dan pengrajin kain tenun endek. Dan memberikan kuesioner kepada responden.

Untuk mengidentifikasi faktor internal (kekuatan dan kelemahan) dan faktor ekternal (peluang dan tantangan) dalam UMKM Kota Denpasar digunakan analisis SWOT. Analisis SWOT Ini di identifikasi berbagai faktor secara sistematis untuk merumuskan strategi perusahaan. Analisis ini didasarkan pada logika yang dapat memaksimalkan kekuatan (strengths) dan peluang (opportunities), namun secara bersamaan dapat meminimalkan kelemahan (weaknesses) dan ancaman (threats).

Analisis kemudian disusun dengan menggunakan kerangka formulai strategis sebagai berikut.

\section{Tahap Pengumpulan Data}

$\begin{array}{llr}\text { Evaluasi Faktor } & \text { Evaluasi Faktor } & \text { Matrik } \\ \text { Ekternal } & \text { Internal } & \text { Profil }\end{array}$

\section{Tahap Analisis}

Tabel 1. Tahap Analisis

\begin{tabular}{|c|c|c|c|c|}
\hline Matrik & Matrik & Matrik & Matrik & Matrik \\
\hline Tows & BCG & Internal & Space & Grand \\
\hline & & & Eksternal & Strategi \\
\hline
\end{tabular}

3. Tahap Pengambilan Keputusan

Matrik Perencanaan Strategi Kuantitatif.
Setelah masing-masing aspek dibobotkan, selanjutnya diadakan penilaian dengan menggunkan hasil identifikasi SWOT, seperti pada tabel berikut.

Tabel 2. Pembobotan SWOT

\begin{tabular}{|l|l|l|l|l|}
\hline $\begin{array}{c}\text { Aspek } \\
\text { Internal atau } \\
\text { E kternal }\end{array}$ & \multicolumn{1}{|c|}{ Nilai } & Rating & Bobot & \multicolumn{1}{c|}{$\begin{array}{l}\text { Skor } \\
\text { tertimbang }\end{array}$} \\
\hline $\begin{array}{l}\text { Faktor kunc } \\
\text { sukses }\end{array}$ & $\begin{array}{l}\text { Sangat kuat, } \\
\text { kuat } \begin{array}{r}\text { 1emah, } \\
\text { paling lemah }\end{array}\end{array}$ & & $\begin{array}{l}\text { Presentase } \\
\text { tersetuju }\end{array}$ & $\begin{array}{l}\text { Rating x } \\
\text { bobot }\end{array}$ \\
\hline TOT AL & & & & Skor Total \\
\hline
\end{tabular}




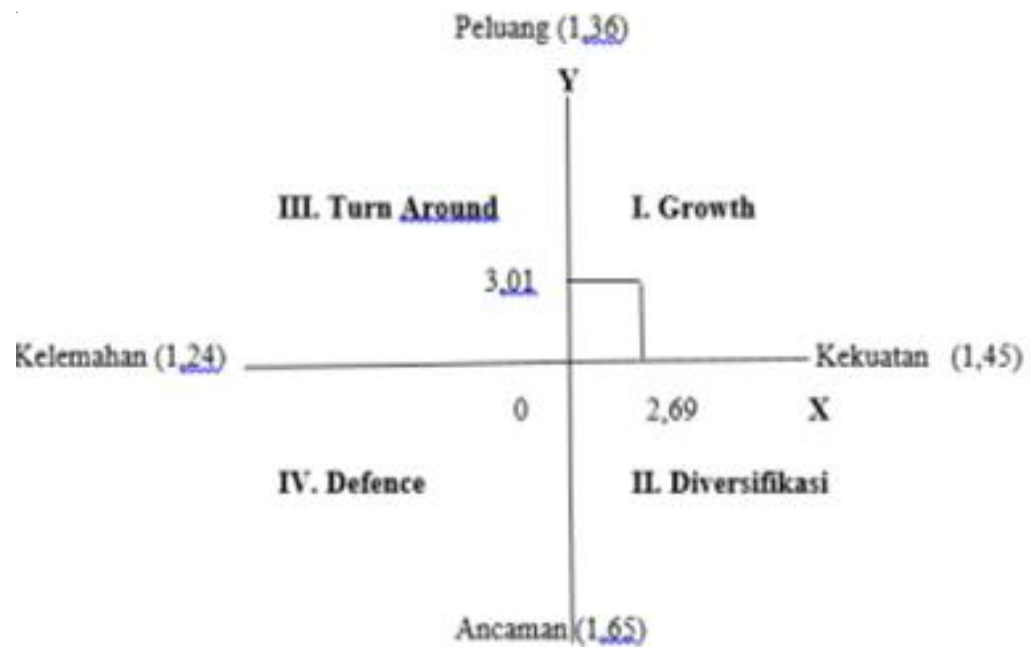

Gambar 1. Matriks Internal dan Eksternal

Langkah seterusnya dibentuk diagram SWOT dibentuk diagram analisis SWOT dengan cara pembobotan terhadap variable-variabel terukur (aspek kekuatan, kelemahan, peluang, dan ancaman. Hal ini sejalan dengan grafik berikut.

\section{Matrik Internal dan Eksternal}

\section{HASIL PENELITIAN DAN}

\section{PEMBAHASAN}

Minat masyarakat Kota Denpasar dalam wirausaha industry kain tenun cukup tinggi dan membuka peluang usaha kain tenun endek. Terdapat 18 pengusaha kain tenun endek yang berada di Kota Denpasar yang sekaligus menjadi responden. Nama usaha maupun pemilik kain tenun endek tersebut antara lain sebagai berikut.

Tabel 3. Responden/Informan

\begin{tabular}{|l|l|}
\hline \multicolumn{1}{|c|}{ Nama Usaha } & \multicolumn{1}{c|}{ Nama Pemilik } \\
\hline Tenun Kebaya Lukis & Ibu Ana \\
\hline Tenun Sekar Jepun & $\begin{array}{l}\text { Etmy Kustiyah } \\
\text { Sukarsa }\end{array}$ \\
\hline Tenun Patra & I Gusti Made Arsawan \\
\hline Tenun Kwaca & Ibu Sari \\
\hline Tenun Ikat Bali & $\begin{array}{l}\text { I Gusti Ayu Agung } \\
\text { Istri Sari Dewi }\end{array}$ \\
\hline Tenun Ikat Perdana & I Made DananTenaya \\
\hline Tenun CV Galleri & Ni Kadek Parwati \\
\hline
\end{tabular}

Tabel 3. Responden/Informan (Lanjutan)

\begin{tabular}{|l|l|}
\hline Tenun Ikat Saraswati & Ibu Saras \\
\hline Tenun Artha Dana & Artha Dana \\
\hline Tenun Suka & A gung Made Sani \\
\hline $\begin{array}{l}\text { Tenun Bali } \\
\text { Insfratruktur }\end{array}$ & H Imam B udijono \\
\hline Tenun Lahae & Naomi Saingo \\
\hline Tenun Sri Puspa & Nyoman Sarmi \\
\hline Tenun Agung B ali & A A Indra Dwipayani \\
\hline Tenun Ikat & Ni Kadek Widiasih \\
\hline $\begin{array}{l}\text { Tenun Kesara Bali } \\
\text { Endek }\end{array}$ & $\begin{array}{l}\text { Ni Luh Gede } \\
\text { Sumertini }\end{array}$ \\
\hline Tenun Ketut Sukarsa & Mangku Ketut Sukarsa \\
\hline Tenun Puri endek & Ida Bagus Ketut Arga \\
\hline
\end{tabular}

Sumber: Data diolah, 2020

Berdasarkan hasil identifkasi posisi strategis industri kain tenun endek bahwa faktor eksternal peluang yang dimiliki industri kerajinan kain tenun endek 1,54 ini relative masih besar, walaupun memiliki skor nilai yang lebih kecil dibandingkan dengan faktor ancaman 0,99. Kondisi ini mengindikasikan bahwa industri kerajinan kain tenun endek masih dapat memanfaatkan peluang eksternal yang memberikan keuntungan bagi usaha kerajinan ditengah ancaman yang juga harus dihadapi oleh industri kerajinan kain tenun endek seperti saat ini yaitu pandemic covid-19.

Survey kemudian diberikan kepada 18 responden tersebut. Dari hasil kuesioner, dilakukan analisis faktor secara eksternal berupa peluang dan 
ancaman, serta analisis faktor internal berupa kekuatan dan kelemahan. Hasil dari survey dapat dilihat melalui tabel berikut. Komponen faktor internal dapat dilihat melalui tabel untuk matriks IFE, adapun komponen faktor eksternal dapat dilihat melalui tabel untuk matriks EFE berikut.

Tabel 4. Matriks IFE

\begin{tabular}{|c|c|c|c|c|c|}
\hline No & Komponen Faktor Ekternal (Peluang) & Signifikansi & Bobot & Rating & Skor \\
\hline 1 & Dukungan Pemerintah atas eksistensi UMKM tinggi & 3,67 & $6 \%$ & 4 & 0,213 \\
\hline 2 & UMKM dapat bersaing di pasar dunia & 3,56 & $6 \%$ & 3 & 0,185 \\
\hline 3 & Subsidi Pemerintah bagi pelaku UMKM & 3,56 & $6 \%$ & 3 & 0,188 \\
\hline 4 & Jumlah penduduk semakin meningkat & 3,56 & $6 \%$ & 4 & 0,203 \\
\hline 5 & Tingkat permintaan produk tinggi & 3,44 & $5 \%$ & 4 & 0,197 \\
\hline 6 & Infratruktur komunikasi dan informasi & 3,44 & $5 \%$ & 3 & 0,182 \\
\hline 7 & Penggunaan Teknologi untuk memasarkan prodak & 3,44 & $5 \%$ & 3 & 0,167 \\
\hline 8 & Pangsa pasar masih tinggi & 3,44 & $5 \%$ & 4 & 0,215 \\
\hline & \multicolumn{4}{|l|}{ Total } & 1,549 \\
\hline No & \multicolumn{5}{|l|}{ Komp onen F aktor E kternal (Ancaman) } \\
\hline 1 & Jumlah Pesaing meningkat & 3,33 & $5 \%$ & 2 & 0,087 \\
\hline 2 & Hambatan masuk pasar/akses pasar terbatas & 3,50 & $5 \%$ & 2 & 0,100 \\
\hline 3 & Globalisasi & 3,28 & $5 \%$ & 2 & 0,082 \\
\hline 4 & Produk pesaing & 3,33 & $5 \%$ & 2 & 0,089 \\
\hline 5 & Kebiasaan pelanggan & 3,28 & $5 \%$ & 2 & 0,091 \\
\hline 6 & Perubahan cara pandang & 3,22 & $5 \%$ & 2 & 0,081 \\
\hline 7 & Meningkatnya harga bahan baku & 3,22 & $5 \%$ & 2 & 0,092 \\
\hline 8 & Muncul banyak pengusaha baru & 3,22 & $5 \%$ & 1 & 0,070 \\
\hline 9 & Lesunya perekonomian & 3,28 & $5 \%$ & 2 & 0,102 \\
\hline 10 & Perubahan gaya hidup konsumen & 3,06 & $5 \%$ & 2 & 0,095 \\
\hline 11 & Regenerasi muda kurang & 3,33 & $5 \%$ & 2 & 0,104 \\
\hline \multicolumn{5}{|c|}{ TOTAL } & 0.993 \\
\hline
\end{tabular}

Sumber: Data diolah, 2020

Tabel 5. Matriks EFE (Faktor Eksternal)

\begin{tabular}{|c|l|r|r|r|c|}
\hline No & \multicolumn{1}{|c|}{ Komponen Falsor Ekternal (Peluang) } & Signifikansi & Bobot & Rating & Skor \\
\hline 1 & Dukungan Pemerintah atas eksistensi UMKM tinggi & 3,67 & $6 \%$ & 4 & 0,213 \\
\hline 2 & UMKM dapat bersaing di pasar dunia & 3,56 & $6 \%$ & 3 & 0,185 \\
\hline 3 & Subsidi Pemerintah bagi pelaku UMKM & 3,56 & $6 \%$ & 3 & 0,188 \\
\hline 4 & Jumlah penduduk semakin meningkat & 3,56 & $6 \%$ & 4 & 0,203 \\
\hline 5 & Tingkat permintaan produk tinggi & 3,44 & $5 \%$ & 4 & 0,197 \\
\hline 6 & Infratruktur komunikasi dan informasi & 3,44 & $5 \%$ & 3 & 0,182 \\
\hline 7 & Penggunaan Teknologi untuk memasarkan prodak & 3,44 & $5 \%$ & 3 & 0,167 \\
\hline 8 & Pangsa pasar masih tinggi & 3,44 & $5 \%$ & 4 & 0,215 \\
\hline & Total & & & $\mathbf{1 , 5 4 9}$ \\
\hline
\end{tabular}


Tabel 5. Matriks EFE (Faktor Eksternal) (lanjutam)

\begin{tabular}{|c|l|r|r|r|c|}
\hline No & Komponen Faltor Ekternal (Ancaman) & \multicolumn{5}{l|}{} \\
& & 3,33 & $5 \%$ & 2 & 0,087 \\
\hline 1 & Jumlah Pesaing meningkat & 3,50 & $5 \%$ & 2 & 0,100 \\
\hline 2 & Hambatan masuk pasar/akses pasar terbatas & 3,28 & $5 \%$ & 2 & 0,082 \\
\hline 3 & Globalisasi & 3,33 & $5 \%$ & 2 & 0,089 \\
\hline 4 & Produk pesaing & 3,28 & $5 \%$ & 2 & 0,091 \\
\hline 5 & Kebiasaan pelanggan & 3,22 & $5 \%$ & 2 & 0,081 \\
\hline 6 & Perubahan cara pandang & 3,22 & $5 \%$ & 2 & 0,092 \\
\hline 7 & Meningkatnya harga bahan baku & 3,22 & $5 \%$ & 1 & 0,070 \\
\hline 8 & Muncul banyak pengusaha baru & 3,28 & $5 \%$ & 2 & 0,102 \\
\hline 9 & Lesunya perekonomian & 3,06 & $5 \%$ & 2 & 0,095 \\
\hline 10 & Perubahan gaya hidup konsumen & 3,33 & $5 \%$ & 2 & 0,104 \\
\hline 11 & Regenerasi muda kurang & & & & $\mathbf{0}, 993$ \\
\hline TOT AL & & & &
\end{tabular}

Sumber: Data diolah, 2020

Beberapa peluang eksternal tersebut adalah dukungan pemerintah atas eksitensi umkm tinggi, umkm dapat bersaing dipasar dunia, subsidi pemerintah bagi pelaku umkm, sehingga secara ekonomis menjaga permintaan pasar dan stabilitas harga bahan baku, peningkatan kesejahteraan masyarakat sejalan dengan perbaikan ekonomi, infrastruktur yang semakin baik dan semakin bersaingnya industry kerajinan baik di pasar lokal maupun pasar global. Sementara ancaman yang dihadapi industri kain tenun endek adalah jumlah persaingan yang semakin meningkat, hambatan masuk pasar, globalisasi, prodak pesaing, kebiasaan pelanggan, perubahan cara pandang, meningkatnya harga bahan baku, munculnya banyak pengusaha baru,lesunya perekonomian, perubahan gaya hidup konsumen, regenerasi muda kurang. Kondisi internal dan eksternal yang dihadapi industri kain tenun endek menuntut pentingnya strategi pemberdayaan usaha yang komprehensif dan integrative yang bukan hanya untuk mencapai tujuan jangka pendek yaitu keuntungan usaha namun juga tujuan jangka panjang yaitu kontinuitas usaha baik produksi dan pasar.

\section{Matriks SWOT}

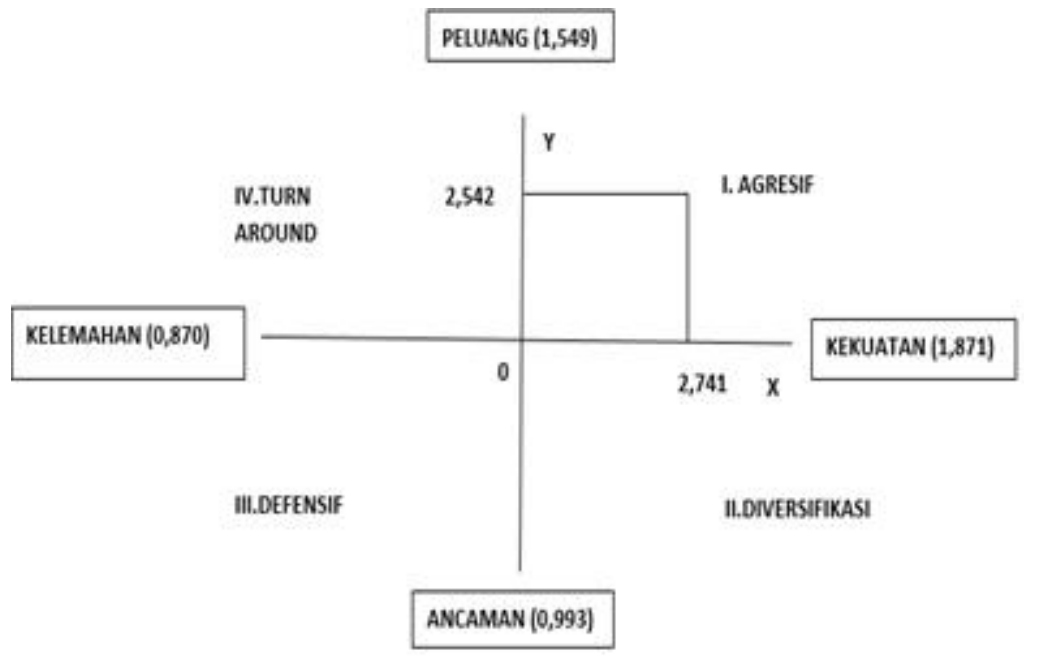

Gambar 2. Matriks SWOT 
Setelah mengetahui posisi perusahaan di kuadran satu dimana strategi yang paling sesuai adalah strategi agresif dimana strategi ini adalah staregi yang

menunju kemajuan dari perusahaan.

Analisis Matriks SWOT

Total Nilai IFE

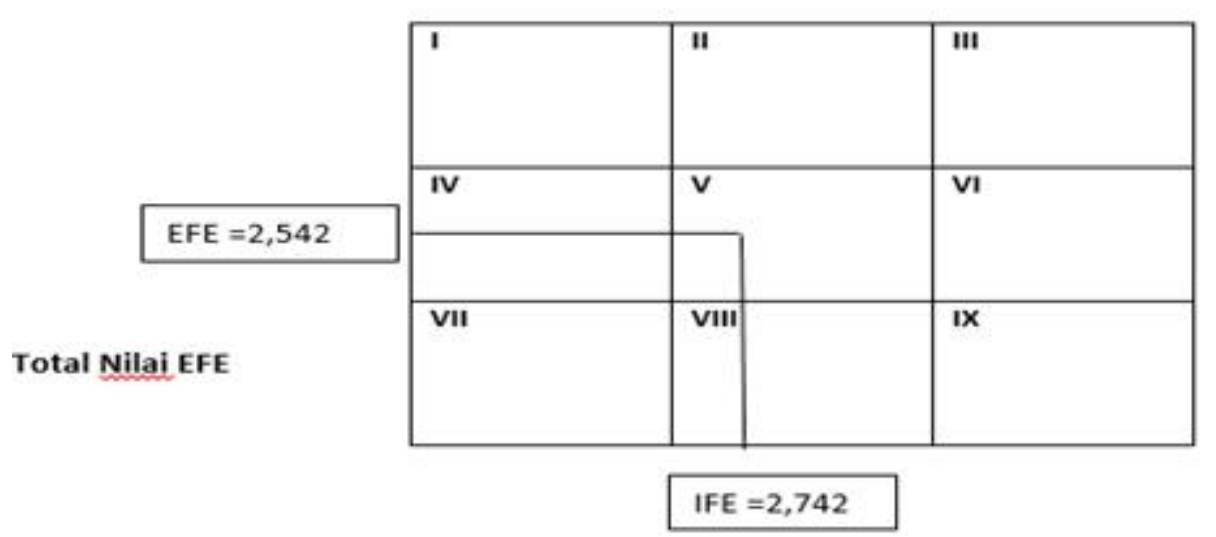

Sumber: Data diolah, 2020

\section{Gambar 3. Analisis Matriks SWOT}

Posisi bisnis industri kain tenun endek pada kuadran ke $\mathrm{V}$ dan strategi yang sesuai adalah strategi pertumbuhan dengan konsentrasi melalui integrasi horizontal. Strategi pertumbuhan melalui intergrasi horizontal menurut Wheelen \& Hunger (2012) dari sisi internal hendaknya segmen pasar diperluas menjadi lebih besar, dan didukung strategi dari analisis SWOT. Solusi yang dapat dilakukan ketika berada pada kuadran $\mathrm{V}$ dan didukung strategi dari analisis SWOT antara lain: (1) peningkatan segmen pasar dengan memperluas daerah pemasaran; (2) melakukan kerjasama dengan perusahaan sejenis; (3) fokus pada sumber daya manusia; dan (4) peningkatan yang berkelanjutan.

\section{PENUTUP}

Dari analisis yang dilakukan terhadap lingkungan internal dan eksternal maka dapat diambil dua simpulan. Simpulan pertama strategi pengembangan Kain Tenun Endek di Kota Denpasar, dilihat dari hasil perhitungan matrik Internal dan Ekternal, posisi Industri Kain Tenun Endek di Kota Denpasar berada pada kuadran I strategi agresif dimana strategi ini merupakan startegi uang menunjukan kemajuan dari perusahaan, pada kuadran
I dalam diagram analisis SWOT. Ini merupakan situasi yang menguntungkan karena memiliki kekuatan yang cukup untuk memanfaatkan peluang, sehingga perusahaan dapat melakukan strategi pertumbungan agresif (Growth Oriented Strategy). Simpulan kedua, posisi bisnis industry kain tenun endek pada kuadran ke V dan strategi yang sesuai adalah strategi pertumbuhan dengan konsentrasi melalui integrasi horizontal.

Pemerintah diharapkan dapat memantu memperkenalkan prodak hasil industri para pengerjaini kain tenun endek, dengan selalu megadakan pameran-pameran, dan pemerintah juga harus berkomitmen membantu para pengerajin lokal untuk tetap eksis lewat pemasaran berbasis plarform digital yang sangat cocok diterapkan dimasa pandemi dengan berpedoman pada protokol kesehatan covid19. Pemerintah daerah juga perlu meningkatkan penyelenggaraan pendidikan dan pelatihan dengan tujuan untuk meningkatkan kualitas dan kuantitas, sekaigus memotivasi generasi muda agar generasi muda menumbuhkan minat terhadaap kerajinan tenun. Pengerajin harus jelas dan konsisten pempertahankan kreativitas dan kualitas produk yang dipasarkan sehingga konsumen tetap bisa mendapat produk yang dipasarkan lewat marketplace, dan tetap 
menggunakan bahan baku serta alat yang baik dan memadai.

Penelitian dengan memakai matriks SWOT dan IE ini mempunya kelemahan yakni tunduk pada waktu dan subjektif. Sehingga diharapkan pada penelitian berikutnya, dapat menggunakan model matriks lainnya yang mampu menghasilkan data yang lebih akurat.

\section{DAFTAR PUSTAKA}

[1] Ardiansyah, Tedy. 2016. Model Pengembangan Wirausahawan Usaha Mikro, Kecil dan Menengah (UMKM) yang Sukses. Jurnal Sosio E-Kons Vol. (8). No (1).

[2] Arifianto, Endra Yuafanedi; Himawan, Rakhmat. 2018. Strategi Pengembangan Industri Kreatif Kerajinan Topeng Era Industri. Jurusan Teknik Industri, Fakultas Teknik, Universitas Brawijaya. Publikasi Ilmiah Prosiding Seminar Nasional IENACO.

[3] Asriati, Nuraini. 2019. Strategi Pengembangan Entrepreneurship di Kabupaten Bengkayang. Proceedings International Conference on Teaching and Education (ICoTE) Vol. 2

[4] Balbir B; Venkataramany, Sivakumar 2010. Globalization of Entrepreneurship: Policy Considerations for SME Development in Indonesia. The International Business \& Economics Research Journal. 9.4 ProQuest

[5] Chandler, Alfred. 2014. Strategy and Structure: Chapters in The History of American Industrial Enterprice. Wiley, New York.

[6] Dinas Koperasi Kota Denpasar. 2019. Data UMKM Kota Denpasar. http:// ukmdiskop.denpasarkota.go.id/

[7] Endaryono, Bakti Toni; Djuhartono, Tjipto. 2018. Membangun Jaringan Pasar untuk Mengembangkan Usaha Produk Lokal
Dalam Menumbuh Kembangkan Usaha Berbasis Sumber Daya Lokal Melalui Usaha Mikro dan Keuangan Mikro. Jurnal Sosio E-Kons Vol 10 No (3)

[8] Endaryono, Teguh. 2016. Identifikasi Motivasi Wirausaha Perempuan Pedesaan dengan Hadirnya Mitra Pembangun Berdasarkan Pendekatan Teori Harapan. Jurnal Manajemen, Strategi Bisnis dan Kewirausahaan, [S.1.], p. 179 - 189.

[9] Fitriasari, Fika. 2017. Strategi Pengembangan Pembiayaan Usaha Mikro Kecil dan Menengah(UMKM) Di Indonesia.

[10] Hunger, J.D. dan Wheelen, T.L. 2012. Strategic Management and Bussiness Policy: Toward Global Sustainability (13th Edition). Pearson. New York.

[11] Iban, Sofyan. 2015. Manajemen Strategi. Graha Ilmu, Yogyakarta.

[12] Kartajaya, Hermawan. 2017. Citizens 4.0. Gramedia, Jakarta.

[13] Kementerian Koperasi, Usaha Mikro, Kecil, dan Menengah. 2008. Undang Undang Republik Indonesia Nomor 20 Tahun 2008 Tentang Usaha Mikro Kecil dan Menengah.

[14] Kota Denpasar Dalam Angka 2019. Badan Pusat Statistik Provinsi Bali. www.denpasarkota.bps.go.id.

[15] Kotler, Philip; Kartajaya, Hermawan; Setiawan, Iwan. 2017. Marketing 4.0. Wiley, New York.

[16]Lestari, Nina Eka. 2014. Strategi Pengembangan Industri Kerajinan Ukiran Kayu di Kabupaten Gianyar Prov. Bali. Disertasi Program Doktor, Program Studi Ilmu Ekonomi, Program Pascasarjana Universitas Udayana. Diterbitkan.

[17] Marsudi, Almatius; Widjaja, Yunus. 2019. Industri 
4.0 dan Dampaknya Terhadap Financial Technology Serta Kesiapan Tenaga Kerja Di Indonesia. Ikraith Ekonomika Vol.2 No.2

[18] Nurcahyani, L. 2018. Strategi Pengembangan Produk Kain Tenun Ikat Sintang. Jurnal Pendidikan dan Kebudayaan, 3(1), 56 -72.

[19] Nurjannah, Siti; Sahuri, Chalid. 2014. Efektivitas Pelaksanaan Program Pengembangan Kewirausahaan Usaha Mikro Kecil dan Menengah Oleh Dinas Koperasi Usaha Mikro Kecil dan Menengah Kota Pekanbaru. Jurnal Online Mahasiswa JOM Fisip Universitas Riau Vol. 1 No. 2.

[20] Rangkuti, F. 2008. The Power of Brands. Gramedia Pustaka Utama, Jakarta.

[21]Rangkuti, Freddy. 2014. Analisis SWOT: Teknik Membedah Kasus Bisnis. PT Gramedia Pustaka Utama, Jakarta.

[22]Savitri, Astrid. 2019. Revolusi Industri 4.0: Mengubah Tantangan Menjadi Peluang di Era Disrupsi 4.0. Genesis, Yogyakarta.

[23]Singgih, M. N. 2006. Strategi Penguatan Usaha Mikro Kecil Menengah (UMKM) Sebagai Refleksi Pembelajaran Krisis Ekonomi Indonesia. Jurnal Ekonomi Modernisasi, 3(3), 218-227.

[24]Sriasih, Ketut; Adi, Yudana. 2016. Menciptakan Keunggulan Bersaing UKM Berbasis Kewirausahaan. Prosiding Seminar Nasional 2016 Inovasi IPTEKS Perguruan Tinggi untuk Meningkatkan Kesejahteraan Masyarakat dari Lembaga Penelitian dan Pemberdayaan Masyarakat (LPPM) Unmas Denpasar 29-30

[25]Stephanie, K. Marrus. 2018. Desain Penelitian Manajemen Strategik. Rajawali Press, Jakarta.

[26]Sugiyono. 2018. Metode Penelitian Kuantitatif, Kualitatif, dan $R \& D$. AFABETA. Bandung.
[27]Sukaatmadja, Gde; Yasa, Kerti.; Rahyud, Henny; Widagda, Jaya. 2014 Strategi Pengembangan Pasar Tradisional Berbasis Kearifan Lokal untuk Mengentaskan Kemiskinan di Bali. Jurnal Manajemen, Strategi Bisnis dan Kewirausahaan: Volume 8 Nomor 2

[28]Suryadi, Dedy. 2018 Peran dan Strategi Perkembangan Kewirausahaan dan Tantangannya Dalam Menghadapi Perekonomian di Masa Yang Akan Datang. Dampaknya Terhadap Financial Technology Serta Kesiapan Tenaga Kerja di Indonesia. Jurnal Universitas Bale Bandung, No. 1-14.

[29]Tahwin, Muhammad; Aviv, Mahmudi A. 2014. Strategi Pengembangan Usaha Batik Tulis Lasem Dengan Analisis SWOT. Fokus Ekonomi Vol. 9 No. 2

[30]Umar, Husein. 2002. Metode Riset Bisnis Gramedia Pustaka Utama. Jakarta.

[31]Umar, H. 2005. Strategic Management in Action. PT Gramedia Pustaka Utama, Jakarta.

[32]Wahjusaputri, Sintha; Siregar, Ahmad Faisal. 2017. Kewirausahaan (Entreprenuership) Berbasis Manajemen Strategik bagi Wirausaha Baru di Kecamatan Kebayoran Lama Utara, Jakarta Selatan.

[33]Wilantara, Susilawati. 2016. Strategi \& Kebijakan Pengembangan UMKM. Refika Aditama, Bandung. 